\title{
The role of the 'Vision' course in the creation of the Design programmes in Argentina
}

In 1951 a series of events linked to the future of design were underway in Argentina. Concrete art was slowly becoming a broader project related to the synthesis of the arts. The encounter between Tomás Maldonado and Max Bill (García, 2011) and the bond between local Concretism and so-called 'Billism' marked the beginning of a tradition in which ideas of synthesis, simplicity, beauty and truth appeared together.

This story, fundamental discourse in the construction of design as a discipline in Argentina, found a cornerstone in the magazine nueva visión. Published between 1951 and 1957 , nueva visión provided a platform for the debates on modern architecture and modern art as well as for the local development of the theory of Good Form (Crispiani, 2004, 2011; Devalle, 2009).

The crucial role of this magazine has overshadowed the role that university courses such as 'Vision' had in the construction of an early discourse about design in Argentina - a discourse that articulated the language of modern architecture and modern art. The purpose of this presentation is to discuss the main features of this university course created in 1956, whose mission was to update the architectural education in Argentina under the model of Bauhaus.

keywords design, 'vision' course, university, Argentina, the 1950 `s

\section{Introduction}

\section{Becoming Modern}

With the creation in 1948 of the School of Architecture and Urbanism (FAU) at the University of Buenos Aires (UBA), a series of profound changes began: a space was created for the subsequent opening of design courses in the Argentina universities.

It is important to note that this occurred in an international context of great changes. By the late 1940 S Europe was beginning to process the traumatic experience of the Second World War, while ascribing to the American model of industrialist capitalism. It was not long before such international changes made an impact on Latin America. In Argentina they provoked an abrupt change in the protectionist and state-controlled economic and cultural policies that Juan Domingo Perón had established during his first term as 
president, supported by the figure of Evita (1946 - 1952)'. Until then, the cultural policies of the Peronist government were particularly irritating to the eyes of Argentina's liberal tradition, natural ruler of the educational institutions in the country (Devalle 2009: 234).

In that context, the creation in the mid 1940 of the Schools of Architecture came on one hand to resolve the passage of the 'architect / artist' or 'engineer / architect' to its status as an autonomous professional, but on the other, resulted in the adscription of the newly created institutions to the previously mentioned debates, extending the understanding of Architecture over the conflict between Peronism and the universities.

The arguments were based on a series of university laws enacted in 1947 that swept the liberal tradition from the academic institutions while trying to install the concept of 'social democracy' in the small population of the universities. For the Peronists, it meant the recovery of the true meaning of democracy to the extent that these laws universalized the possibility of accessing university. For the detractors, it meant the loss of autonomy as well as censorship and persecution (Cirvini 2004: 127).

It is important to mention that there were only six universities in Argentina at that time - and they were all public: Buenos Aires, Córdoba, La Plata, Litoral, Tucumán and Cuyo. The most interesting case is that of the University of Tucumán as it marks the feasibility of teaching based on the principles of modern architecture. In fact, the bibliography used in 1947 by Eduardo Sacriste, one of the Professors of the Department of Architecture, included Complete Works by Le Corbusier, Technics and Civilization by Lewis Mumford, the Athens Charter and the works of F. L. Wright.

However, and with the exception of the Tucumán case, although the university plans were changed and the Faculties were created, curriculum content was still responding to the traditional teaching of the French Beaux Arts, in which architecture was understood as Art.

But Argentina had not been left aside from the rest of the world. The interwar years had celebrated the visit of prestigious international figures. Among those visits were Le Corbusier in 1929, Werner Hegemann, Pietro Bardi and Alberto Sartoris, whose public lectures stimulated those who were interested in the European debates (Garcia 2011: 130-139).

Moreover, the local and modern production was welcomed by the students in the late 1930's an early 1940's. New horizons were opened to think about the new architectural theories and new teaching models. This way of thinking was developed over Peronism but really came into shape in 1955 when Peron was ousted by a civilian-military coup.

In the early 1950 s the opportunity arrose to inaugurate the discussion and make public the rejection to the model of the Academies of Arts, and incidentally, to mark the

\footnotetext{
Juan Domingo Perón was elected president of Argentina in 1946 and reelected in 1952. In his first two presidencies he implemented an industrialist economic policy that was opposite to the agricultural profile that Argentina's economy had always had. This change favored the development of industries and the creation of university courses related to industry. In cultural terms Perón's government was defined by a strong questioning of the elite's liberal traditions that had dominated the cultural scene in Argentina's large cities such as Buenos Aires. This combination of great popular support with the rejection of liberal Europeanized traditions motivated the labeling of the Peronist government as populist and the rejection of most university professors. Perón was ousted in 1955 by a civilianmilitary coup that restored the liberal tradition in educational institutions, particularly universities. This meant restoring a vision that valued everything produced in Europe and undervalued or even ignored the productions from Latin America.
} 
students opposition to the Peronist government. By then, some students had developed workshops and discussion groups on modern art and architecture as an alternative to the official programmes. This was the start of a new model for the understanding of the practice, which would go beyond a new architecture methodology. In this way, new ideas related to the issue of the 'human needs', the function of the building and the social use of housing were started to be discussed by students.

By 1956, with the so-called 'opening' of the University after Peronism, these young graduates began their careers as teachers and took part in the creation of new courses and the updating of teaching material. Ferrari Hardoy, for instance, was invited to reorganize the School of Rosario where he formed a teaching team that brought innovative ideas for the structure of the courses changing the teaching methodology of architecture. These ideas, especially the 'vertical workshops', had been unveiled in Montevideo in 1952 and were based on the way Bauhaus worked. They were brought to America by Moholy-Nagy when he emigrated to the US².

The same spirit of integration drove the transformation of the teaching system in the School of Architecture and Urbanism at the UBA from 1957, when Alfredo Casares was appointed as dean. In his deanery, a system of course departments was introduced which allowed for the redefinition of architecture in the light of its main problems. So the Departments of Architecture, History, Techniques and Vision were born. The Vision subject had been created a year earlier by Le Pera in Rosario and it was taught by Breyer, Méndez Mosquera, Onetto and Le Pera himself.

Vision deserves special attention as it turned out to be the place where, for the first time in Argentina's academia, the form was not considered from an artistic point of view, but rather from a technical and scientific one - while being linked to mathematics, psychology, systems theory and semiotics. Teachers like Le Pera, Breyer and Jannello were key to the development of these ideas.

\section{'Vision' in Architecture}

'Vision' was a laboratory where the Bauhaus methodology converged with what was happening in UIm. But what definitely marked the route of the course were the teachings of Moholy-Nagy. They exceeded the limits of the discipline and connected with what Bill had been exploring until recently: the fusion of the arts, the search for universal invariants in the study of the form. In this way, nueva visión and Good Form were the concepts tied in the program of Vision (Carbajal 2005: 25-32).

The ability to view, without composing or representing, brought echoes of the approaches of constructivism and formalist poetry. To view was to assigned entity from the recognition of a range of vision. It was, in artistic terms, the end of the idea of mimesis between object and nature; and in architectural terms it meant analyzing structures, decomposing elements, tracing relationships, establishing symmetry and proportions. Perhaps, this was the reason why Arnoldo Gaite considered the Vision course as 'responsible for formulating the language of the future; the idea that architecture was a

\footnotetext{
${ }^{2}$ It is worth noting that some of these young architects had studied at the New Bauhaus in Chicago, such as the architect Juan Manuel Borthagaray, and the UIm School of Design, in the case of Francisco Bullrich.
} 
prime way to change the world. That was what we thought.'3

'Breyer, Jannello and Onetto are the ones who had a clearer notion of the idea, of the innovation... Especially in the third and fourth levels of the Vision course, where the instrumental stage was already taught, there was a strong impetus for this course to function as the structural basis of Design, which some called Basic Design or Design Foundation. At that time the idea of design was already aligned with the concepts of Bauhaus, and it was understood that it exceeded the field of architecture. Even when the Faculty was (only) an Architecture School there were no other courses - there was a notion of Design that covered other experiences, not only the one of architecture. That is why a lot of people that graduated at that time were the first graphic designers, industrial designers (...) However, the project brought concerns, but was and still is a fantastic project. Like any project it was partly fulfilled and partly left unfinished... like all utopias, there is always a goal that is not met, otherwise would not be a utopia... and it does qualify as such. In this project, one can still continue to be engaged...' ${ }^{4}$

What was the concern? Probably precisely that constituted the main strength of the area: the dissolution of the architectural space and the architectural domain. For those who thought in terms of the consolidation of the discipline, Vision was a new (and confusing) Architecture foundation; for those who consider architecture as a field of interrelated problems, it meant the opening to a larger universe of ideas that exceeded the architectural understanding.

At this moment of change the professionalist idea of Architecture succeeded. So a more operational perspective was imposed which dismantled the conceptual base of Vision and considered instead that the contents should be applicable in a practical and direct way. After the experimental stage where Vision finished, the influence of Moholy-Nagy left Constructivism behind and so did the ever unanswered question of the conditionings of perception.

It can be said that the subject Vision proved to be foundational, as it proposed the development of a theory of the form tied to the paradigm of Good Design and not to the classical parameters of the architectural composition. Good Form and Good Design, equivalent to each other, were closely linked to a modern conception of Architecture. Vision provided the tools for architecture reformulation (Doberti 2008). Carlos Mendez Mosquera remembers:

"The paradigm of the Bauhaus was there when we made the subject "Vision". That was in 1955 and 1956. There, the word "visión", as in the magazine nueva visión, was taken from the new vision - which is definitely a term of MoholyNagy. By the 1950s there was a great change going on. Our idea was to incorporate new subjects, remove traditional methodologies and include new approaches as was the "Vision" course. A new sense of History, of Technology all very focused on Architecture. I, for instance, was really interested in the new approaches and was teaching Typography and Graphic Design in the "Vision" course, but as a tool for the architect, as a useful part for Architecture. It was only in 1964 or 1965 that we wrote the First Document for the creation of the

3 Interview to Arq. Arnoldo Gaite, professor of Vision.

${ }^{4}$ Interview to Arq. Roberto Doberti, professor of Vision. 
Industrial and Graphic Design courses at the University of Buenos Aires. The thing is, initially we had many problems remaking the teaching at the Faculties of Architecture.'5

The way that Vision developed beyond Architecture, can be seen in the distinctiveness of the subject of Morphology in the Design courses both at the National University of La Plata, where the design courses were created in 1963, as well as at the University of Buenos Aires created in 1985. The National University of Cuyo, meanwhile, a pioneer institution in the teaching of Design started giving courses in 1958 was almost a direct consequence of this process, as it is the result of a project by César Jannello.

\section{Conclusion}

This paper has sought to stress the relevance of the Vision course, together with that of the nueva visión magazine, in the re-foundation of Architecture in the 1950's in Argentina. After Vision, the term 'volume' was replaced by 'space', architectural ideas ceased relying on illustration for visual support and 'vision exercises' took over the old 'architectural compositions'. Such transformations broke the traditional barriers that separated the artistic, the architectural and the urban.

In this sense, it can be said that within academia, Design in Argentina, as well as in Brazil and Chile, appears to have some specificity linked to the Modern Architecture discourse and the local update of the Bauhaus tradition. However, the rhetoric of Modernism did not have a massive projection and the much-touted fusion of arts with technology and industry was difficult to accomplish. Despite the instability of a developing discipline with unclear boundaries, the enthusiasm of young Bauhaus-affiliated architects allowed the discourse on Good Form and Good Design to crystallize with unprecedented force. By this definitely achieving the replacement of the Fine Arts model that had dominated architectural education and the inclusion of Industrial Design as an extension of the modern intervention on the human habitats.

\section{References}

Carvajal, G. (2005) Diseño como poética. El pensamiento de César Jannello. Buenos Aires: Academia Nacional de Bellas Artes.

Cirvini, S. A. (2004) Nosotros los arquitectos. Campo disciplinar y profesión en la Argentina moderna. Mendoza: Zeta Editores.

Devalle, V. (2009) La travesía de la forma. Emergencia y consolidación del Diseño Gráfico (1948-1984). Buenos Aires: Paidós.

Doberti, R. (2008) Espacialidades. Buenos Aires: Ediciones Infinito.

García, M. A. (2011) El arte abstracto. Intercambios culturales entre Argentina y Brasil.

Buenos Aires: Siglo XXI. 
